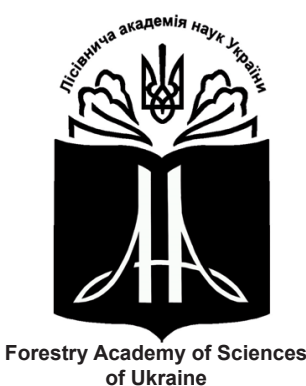

UDC 504.062.2

Наукові праці Лісівничої академії наук України

Proceedings of the Forestry Academy of Sciences of Ukraine

http://fasu.nltu.edu.ua

https://doi.org/ 411716

Article received 2017.09.05

Article accepted 2017.11.15
ISSN 1991-606X print

ISSN 2616-5015 online

(a) $\triangle$ Correspondence author

Anita Zapałowska

anise@interia.pl

\title{
Qualitative analysis of pellets produced from Jerusalem artichoke (Helianthus tuberosus L.)
}

\author{
A. Zapałowska', U. Bashutska²
}

The development of renewable energy constitutes a crucial role for the future as combustion of the plant biomass causes reduction of sulfur oxides and nitrogen oxides. The purpose of the work was to determine the basic energetic and mechanical properties of pellets that were produced from Jerusalem artichoke. The mechanical properties and combustion behaviour were studied by means of mechanical strength (Zwick / Roell Z010) and thermogravimetric (TGA) analysis. The suitability of pellets is determined both by their energy value, which is influenced by biomass moisture, and mechanical durability during their transport and storage. The analyses were conducted in the laboratory of the Department of Bioenergetics and Food Analysis at University of Rzeszów in 2017. The following parameters were analyzed: calorific value, moisture content, ash content, Carbon (C), Nitrogen (N) and Hydrogen (H). The analyzed material was characterized by high mechanical resistance levels. Due to the very high energy value 18,85 MJ/kg and high mechanical durability, both estimated in own studies, it can be stated that Jerusalem artichoke in the form of produced pellets can be used for heating purposes. When the chemical properties were examined, it was found, that the product under consideration had environmentally friendly qualities, and did not emit unpleasant odors. Furthermore, it was mechanically stable, clean, safeand comfortable to use.

Key words: biomass, pellets, mechanical strength, energy value, Jerusalem artichoke.

Introduction. Plant biomass is the oldest and most widely used source of energy. It is an organic matter from plant and animal origin, which is biodegradable. These are residues from forestry, municipal and industrial wastes as well as vegetable matter from agriculture crops (Zabłocki, 2013, Azar, Lindgren, \& Anderson, 2003). Agricultural and forest waste as well as industrial products are available materials for biofuel pellet production. Wood pellets are a clean and convenient fuel. They are mostly produced from sawdust, wood chips and wood shavings. The need for searching new technological solutions using fuels for energy purposes means that the aim is to use both, plant biomass from extra production from agricultural production, and intentionally established energy plantations. That is why the energy plants have been very popular in recent years. One of the main characteristics of energy plants is their significant increase during the year, high calorific value as well as high disease resistance and relatively low soil requirements. Jerusalem artichoke is an energy plant whose tubers can be used for biogas or ethanol production, and the above-ground parts for pellets and fuel briquettes (Piskier, 2013, Kacprzak, Michalska, Romanowska-Duda, \& Grzesik, 2012). By pelletization, raw biomass can be converted into a pellet form with improved fuel quality such as increased bulk density, and uniformed shape and size. Pellets are usually produced from a variety of residue feedstock, it can be straw, sawdust, wood (from agricultural and forest biomass). The most important parameter of utility compacted solid biofuels is their mechanical durability. A high value of this parameter makes the product during transport from the producer to the user and the movement of the fuel to the furnace does not fall apart.

Anita Zapalowska - assist. prof., dr., Department of Bioenergetics and Food Analysis, University of Rzeszów, 35601, Rzeszów, Zelwerowicza St., 4, tel. 177854943, e-mail: ztb-wbr@ur.edu.pl, Poland. Tel.: 0048784702111.E-mail: anise@interia.pl

Ulyana Bashutska - assist. prof., dr., Department of Ecology, Ukrainian National Forestry University, 79057, Lviv, Gen. Chuprynky St., 134, tel.0322388194,e-mail: ecology@nltu.edu.ua,_Ukraine.Tel.00380676837277.E-mail: ulyana_b@ukr.net 
It must be taken into consideration, that pellets made from different plant material are subjected to various types of loads (Niedziółka, Żak, \& Szpryngiel, 2012, Ferreira, PT., Ferreira, \& Teixeira, 2014, Mustelier, A1meida, Cavalheiro, \& Castro, 2012, Kaliyan, \& Morey, 2009). They are mechanically damaged due to both dynamic and static loads associated with transport, reloading or storage (Krzysztofik, \& Wrona, 2014). The mechanical properties and combustion behavior of analyzed material were studied.

Materials and methods. The aim of the study was in mechanical and energetic analysis of pellets made from Jerusalem artichoke. The research material (Fig. 1) was a sample of $1 \mathrm{~kg}$ of pellets from which a representative sample was taken randomly (the number of degrees of freedom for our experiment was 10). The pellet production technology requires a proper fragmentation of the quality and humidity of the material, as well as the right proportions of the material. The production of pellets was carried out using the RAF-AN biomass pelleting line, where the material fed with a screw conveyor with a humidifier met the matrix and was pressed through the holes. The obtained final product in the form of pellets went to the cold store where the excess moisture evaporated and it was finally hardened. The granulate was sieved on a sieve with $3,15 \mathrm{~mm}$ holes. The material for testing static mechanical properties was sifting while the remaining screening was collected on a blind sieve and rejected. After determining the geometrical characteristics of 10 randomly selected pellets such as: diameter, length and weight, using a caliper with an accuracy of $0,01 \mathrm{~mm}$ in accordance with the applicable PN-EN 16127: 2012 standard, the obtained material was subjected to the following determinations according to the PN-EN 14961 standard to examine selected quality features such as:

- mechanical strength; Zwick testing systems were used to determine material characteristics of composites in specific directions, such as compression, shearing and bending for material; the Zwick / Roell Z010 testing machine was used (Fig.2) in accordance with PN-EN 15210-1: 2010;

- calorific value, using the LECO $\AA$ AC500 calorimeter according to PN-EN 14918: 2010 in triplicate;

- Carbon content (C), Nitrogen (N) and Hydrogen (H) using the LECO True-Spec device (CHN module) (Fig.3) in accordance with the PN-EN 15104: 2011 (U) standard;

- moisture content, which was determined using the

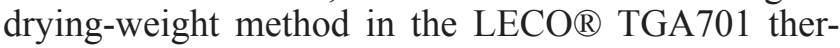
mogravimetric analyzer in accordance with the PN-EN 14774-3: 2009 standard,

- ash content using the LECO® TGA701,

- Statistica 12 and Excel were used to develop the results of the research.

The Shapiro-Wilk test was carried out to check the conformity of the tested parameters with the normal distribution, independent estimation of variance to determine its homogeneity, the one-way ANOVA test was used at the confidence level $\alpha=0,05$.

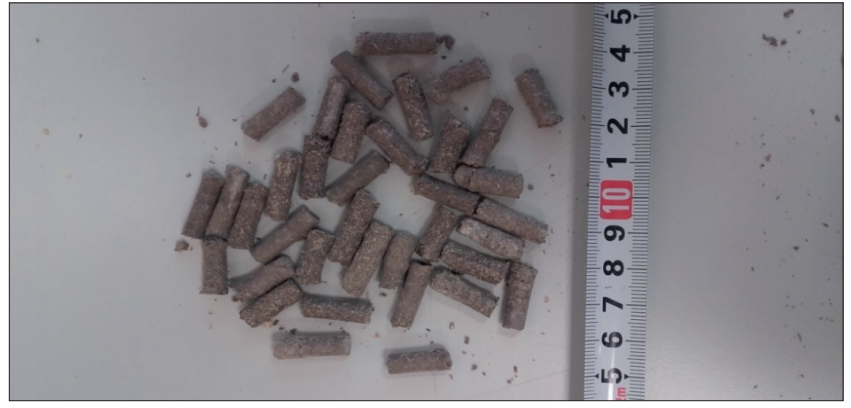

Fig. 1. Pellets from Jerusalem artichoke, own material

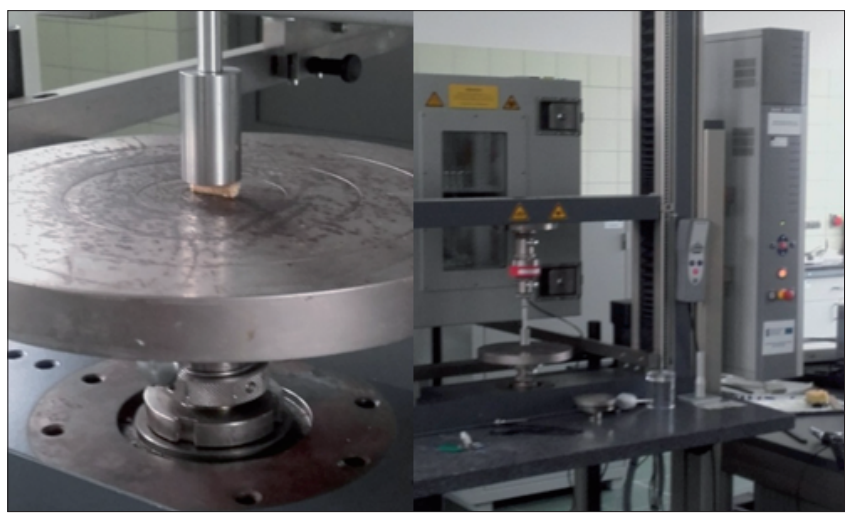

Fig. 2. Zwick / Roell Z010, own material

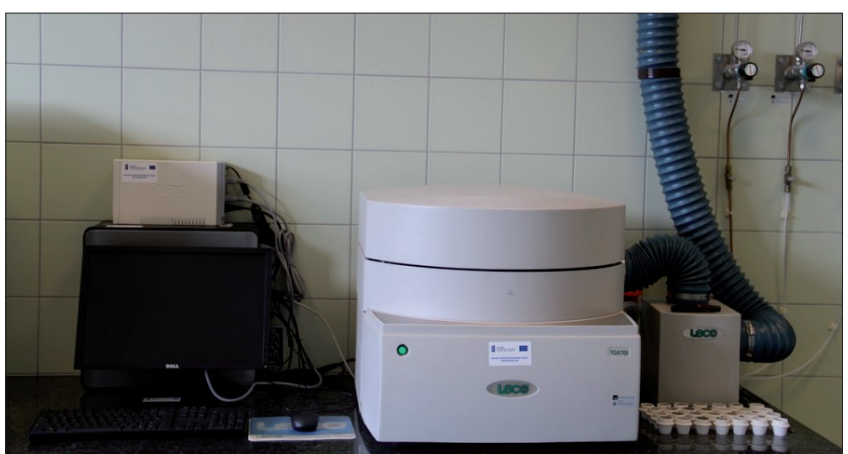

Fig. 3. LECO True-Spec (CHN module), own material

Results and discussion. The following Table 1 and Table 2 show the results of comparative analyzes of energy and mechanical properties of pellets made from above-ground biomass and commonly used pellets being made of conifers and deciduous trees.

The research was mainly based on analyzing pellets properties, in which mechanical properties as well as the moisture content, ash content and calorific value were focused on. These factors affect the combustion process. High energy value of pellets made from Jerusalem artichoke was estimated at $18,85 \mathrm{MJ} / \mathrm{kg}$ in own research. In studies of many authors, this parameter is valued differently, from 12,9 MJ / kg to 19,1 MJ / kg (Wróblewska, Komorowicz, Pawłowski, \& Cichy, 2009, Johansson et al., 2015). If the material has high moisture, it requires more time to be combusted as it has to be dried first. The higher the water content, the lower its energy value. Moisture content, have a leading role in the combustion process because the energy value of the fuel depends mostly on it. It affects the amount of the burnable material which is directly affecting the cost (value), this leads 
to an additional step prior to the combustion (as the fuel shall be dried). For comparison, according to the Technical Specification of fuels from 2010, the average energy value for coniferous wood is $19 \mathrm{MJ} / \mathrm{kg}$, for hardwood $-18 \mathrm{MJ} / \mathrm{kg}$, and much less, about $14 \mathrm{MJ} / \mathrm{kg}$, for straw (PN-EN 14961-1: 2010). In own studies, the durability of pellets from Jerusalem artichoke was above $90 \%$ and was higher than for coniferous and deciduous pellets. This is confirmed by the PN-EN 15210-1: 2010 standard determining the mechanical durability of pellets at over $80 \%$. Based on literature, the best results regarding the mechanical stability of pellets were recorded for pellets produced with a moisture content of $14 \%$ (KowalczykJuśko, 2010).

Tab.1

\section{Physical and chemical properties of Jerusalem artichoke $(T)$ and coniferous and deciduous pellet (P0)}

\begin{tabular}{lcc}
\hline \multicolumn{1}{c}{$\begin{array}{c}\text { Properties } \\
\text { of the material }\end{array}$} & $\mathrm{T}$ & $\mathrm{P} 0$ \\
\hline $\begin{array}{l}\text { Moisture in the dry state (\%) } \\
\text { The calorific value in }\end{array}$ & $6,81 \pm 0,01$ & $8,81 \pm 0,01$ \\
the dry state (MJ / kg) & $18,85 \pm 0,02$ & $16,25 \pm 0,02$ \\
Coalcontent C (\%) & $43,00 \pm 0,01$ & $45,19 \pm 0,01$ \\
Hydrogencontent H (\%) & $6,56 \pm 0,01$ & $5,84 \pm 0,01$ \\
Nitrogencontent N (\%) & $0,69 \pm 0,01$ & $0,59 \pm 0,01$ \\
Ash (\%) & $2,04 \pm 0,03 *$ & $1,83 \pm 0,03$ \\
\hline
\end{tabular}

* $-\mathrm{x} \pm \mathrm{Sd}, \mathrm{x}-$ mean, $\mathrm{Sd}-$ standard deviation

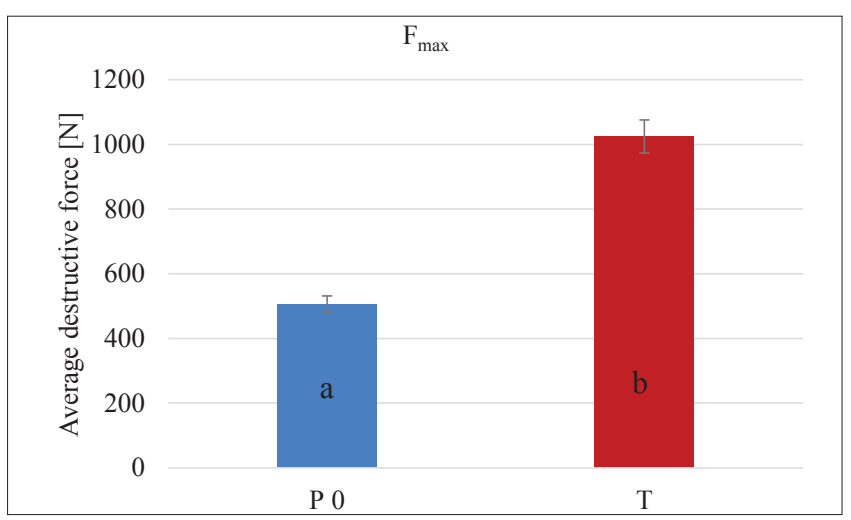

Fig. 4. Relation of the average value of destructive force $\mathrm{F}_{\max }[\mathrm{N}]$ on the type of pellet (P0 and $\left.\mathrm{T}\right), \mathrm{a}, \mathrm{b}$ - statistically significant differences between the analyzed pellet variants separately for each of the analyzed parameters

In our own research, the moisture content of Jerusalem artichoke pellets was estimated at 6,81\%. In comparison, Salix viminalis, which is the most popular energy plant, contains about $6 \%$ moisture. Our research confirms, that Jerusalem artichoke is an unusually valuable energy plant, whose calorific value and the moisture content is comparable with other energy raw materials. The mechanical strength of the pellets is affected by many factors, including compression force and temperature, particle size, and chemical composition of biomass feedstock.

Conclusions. There was noted a higher moisture in the dry state for coniferous and deciduous pellets $(\mathrm{P} 0)$ $8,81 \%$, lower for Jerusalem artichoke epellet (T) 6,81\%.

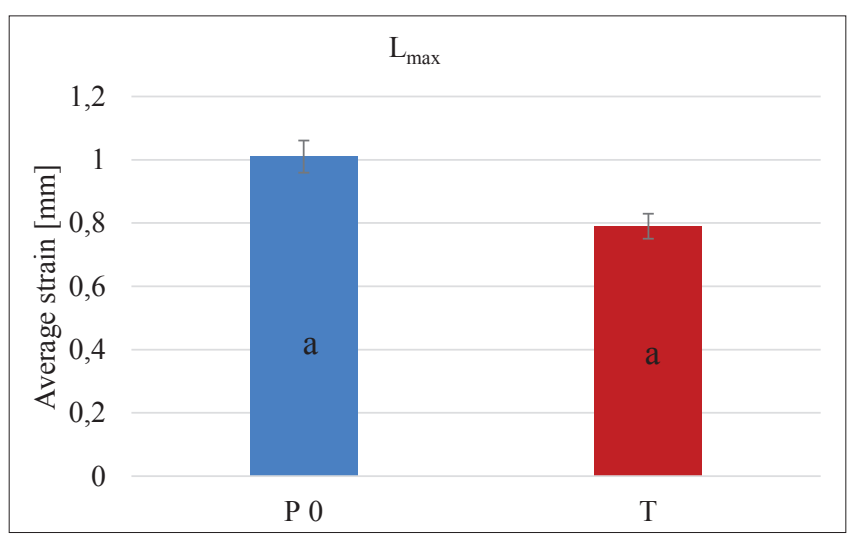

Fig. 5. Relation of maximum strain Lmax [mm] on the type of pellet ( $\mathrm{P} 0 \mathrm{i}$ T), a, b - statistically significant differences between the analyzed pellet variants separately for each of the analyzed

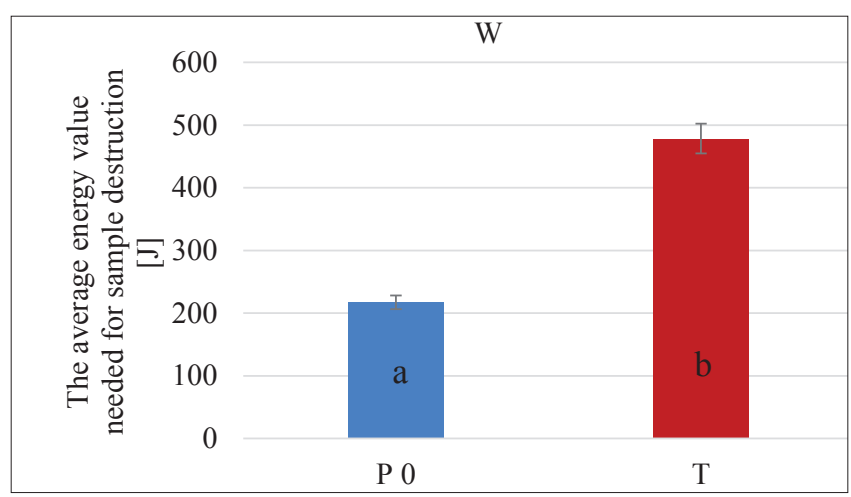

Fig. 6. Relation of the average maximum energy $\mathrm{W}[\mathrm{J}]$ on the type of pellet (P0 and T), needed to destroy sample, a, $\mathrm{b}$ - statistically significant differences between the analyzed pellet variants separately for each of the analyzed

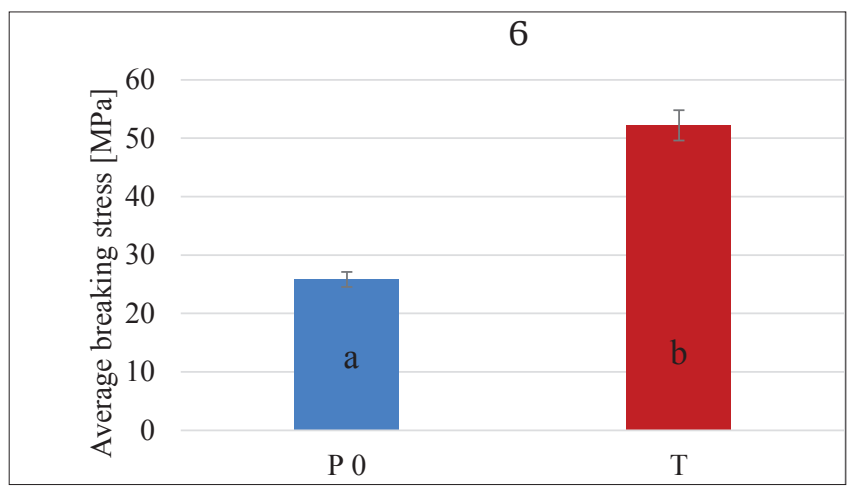

Fig. 7. Relation of average breaking stress $6[\mathrm{MPa}]$ to the type of pellet (P0 and T), a, b - statistically significant differences between the analyzed pellet variants separately for each of the analyzed

The higher energetic value was noted for Jerusalem artichoke (T) 18,85 MJ / kg. For coniferous and deciduous pellets (P0) it was $16,25 \mathrm{MJ} / \mathrm{kg}$.

Elemental analysis showed that pellets from Jerusalem artichoke (T) had a lower Carbon (C) content of $43,0 \%$, higher Hydrogen content $(\mathrm{H})$ of $6,56 \%$ and Nitrogen $(\mathrm{N})$ of $0,69 \%$ compared to coniferous and deciduous pellets ( $\mathrm{P} 0)$ for which the content of the above mentioned elements were respectively: $45,19 \% \mathrm{C}$, $5,84 \% \mathrm{H}, 0,59 \% \mathrm{~N}$. 
Geometric features for Jerusalem artichoke (T) and coniferous and deciduous pellet (P0)

\begin{tabular}{cccccc}
\hline & $\mathrm{T}$ & \multicolumn{3}{c}{ P0 } \\
\hline Diameter $(\mathrm{mm})$ & Length $(\mathrm{mm})$ & Weight $(\mathrm{g})$ & Diameter $(\mathrm{mm})$ & Length $(\mathrm{mm})$ & Weight $(\mathrm{g})$ \\
\hline 6,00 & 6,46 & 2,04 & 6,00 & 6,59 & 2,04 \\
6,00 & 6,24 & 2,02 & 6,00 & 6,63 & 2,05 \\
6,00 & 6,73 & 2,04 & 6,00 & 6,64 & 2,06 \\
6,00 & 6,64 & 2,04 & 6,00 & 6,56 & 2,04 \\
6,00 & 6,28 & 2,02 & 6,00 & 6,59 & 2,04 \\
6,00 & 6,79 & 2,04 & 6,00 & 6,61 & 2,04 \\
6,00 & 6,59 & 2,04 & 6,00 & 6,63 & 2,05 \\
6,00 & 6,16 & 2,01 & 6,00 & 6,64 & 2,06 \\
6,00 & 6,46 & 2,02 & 6,00 & 6,62 & 2,05 \\
6,00 & 6,67 & 2,04 & 6,00 & 6,71 & 2,07 \\
$6,00 \pm 0,00^{*}$ & $6,50 \pm 0,21$ & $2,03 \pm 0,01$ & $6,00 \pm 0,00$ & $6,62 \pm 0,37$ & $2,05 \pm 0,01$ \\
\hline
\end{tabular}

* - the markings see table 1

It was found that the higher ash content is characterized for Jerusalem artichoke pellets (T) 2,04\%, slightly lower for coniferous and deciduous pellets (P0) $1,83 \%$;

The diameter of obtained pellets was the same for both Jerusalem artichoke pellet (T) and coniferous and deciduous pellets (P0) and was $6,0 \mathrm{~mm}$.

The average weight of produced pellets was slightly different: $2,03 \mathrm{~g}$ for Jerusalem artichoke pellets (T) and $2,05 \mathrm{~g}$ for coniferous and deciduous pellets ( $\mathrm{P} 0)$;

The highest resistance to crushing $\left[\mathrm{F}_{\text {max }}\right]$ was noted for Jerusalem artichoke pellet (T) 1024,57 [N], the smallest for coniferous and deciduous pellets (P0) 506,3 [N].

The average values of maximum pellet deformation up to the moment of crushing $\left[\mathrm{L}_{\max }\right.$ ] were in the range of $0,79 \mathrm{~mm}$ for coniferous and deciduous pellets (P0) to $1,01 \mathrm{~mm}$ for Jerusalem artichoke pellet (T0).

The lowest average value of energy needed to crush pellets [W to $\mathrm{F}_{\text {max }}$ ] was recorded for coniferous and deciduous pellets (P0) 217, 30 [J], and the highest Jerusalem artichoke pellet (T) 478,52 [J].

The average value of the stress destroying the pellet structure $6[\mathrm{M} \mathrm{Pa}]$ ranged from $25,80[\mathrm{M} \mathrm{Pa}]$ for coniferous and deciduous pellets $(\mathrm{P} 0)$ to $52,20[\mathrm{M} \mathrm{Pa}]$ for Jerusalem artichoke pellet (T).

Due to the very high energy value estimated in own studies of $18,85 \mathrm{MJ} / \mathrm{kg}$ and high mechanical strength, it can be stated that Jerusalem artichoke (T) in the form of produced pellets can be successfully used for energy purposes. It is an environmentally friendly fuel that does not does not have significant emissions of nitrogen oxides and sulfur dioxide. The pellets do not emit unpleasant odors, they are cheap and ecological.

\section{Referencies}

Azar, C., Lindgren, K., \& Anderson, B.A. (2003). Global energy scenarios meeting stringent $\mathrm{CO}_{2}$ constrains: Cost-effect fuel choices in the transportation sector. Energy Policy, 31, 961-976.

Ferreira, P. T., Ferreira, M.E., \& Teixeira, J.C. (2014). Analysis of industrial waste in wood pellets and co- combustion products. Waste Biomass Valor, 5, 637650. doi: 10.1007/s12649-013-9271-6

Johansson, E., Prade, T., Angelidaki, I., Svensson, S.E., Newson, W. R., Gunnarsson, I. B., Hovmalm, H. P. (2015). Economically Viable Components from Jerusalem Artichoke (Helianthus tuberosus L.). Biorefinery Concept, 16, 8997-9016.

Kacprzak, A., Michalska, K., Romanowska-Duda, Z., \& Grzesik, M. (2012). Rośliny energetyczne jako cenny surowiec do produkcji biogazu. Kosmos, 2, 281-293.

Kaliyan, N., \& Morey, V. (2009). Factors affecting strength and durability of densified biomass products. Biomass Bioenergy, 33(3), 337-359.

Kowalczyk-Juśko, A. (2010). Kompaktowanie się opłaca. Wykorzystuj słomę jeszcze efektywniej. Agroenergetyka, 1, 13-15.

Krzysztofik, B., \& Wrona, P. (2014). Wpływ fizycznych właściwości materiałów roślinnych na ograniczanie ich strat ilościowych i jakościowych, PAN w Lublinie, Lublin, 140-150.

Mustelier, N. L, Almeida, M. F, Cavalheiro, J, \& Castro, F. (2012). Evaluation of pellets produced with undergrowth to beused as biofuel. Waste Biomass Valor, 3, 285-294. doi: 10.1007/s12649-012-9127-5.

Niedziółka, I., Żak, W., \& Szpryngiel, M. (2012). Evaluation of pellets quality produced from chosen raw materials. Agricult. Eng, 2 (137), 231-240.

Piskier, T. (2013). Ze stołu do pieca. Agroenergetyka, 1,38 .

PN-EN 14774-3:2009. Biopaliwa stałe- Oznaczenie zawartości wilgoci-Metoda suszarkowa- Część 3: Wilgoć w ogólnej próbce analitycznej. Wyd. PKN, Warszawa.

PN-EN 14961-1:2010. Biopaliwa stałe - Specyfikacje paliw i klasy - Część 1: Wymagania ogólne. Wyd. PKN, Warszawa.

PN-EN 15210-1:2010. Biopaliwa stałe - Oznaczenie wytrzymałości mechanicznej brykietów i peletów. Wyd. PKN, Warszawa.

PN-EN 14918:2010. Biopaliwa stałe - Oznaczenie wartości opałowej. Wyd. PKN, Warszawa. 
PN-EN 15104:2011 (U). Biopaliwa stałe - Oznaczenie zawartości węgla całkowitego, wodoru i azotu Metody instrumentalne. Wyd. PKN, Warszawa.

PN-EN 16127:2012. Biopaliwa stałe - Określanie długości i średnicy peletów SGR, Sektor Górnictwa

Wróblewska, H., Komorowicz, M., Pawłowski, J., \& Cichy, W. (2009). Chemical and energetically properties of selected lignocelluloses raw materials. Folia Forestalia Polonica. S. B, 40, 67-78.

Zabłocki, M. (2013). Determinanty wykorzystania odnawialnych źródeł energii w Polsce. Wyd. Technika Poszukiwań Geologicznych, Geotermia, Zrównoważony Rozwój, 2, 29-36.

\section{Якісний аналіз гранул, отриманих 3 єрусалимського артишоку (Helianthus tuberosus L.)}

\section{А. Запаловська', У. Башуцька²}

Розвиток відновлюваної енергії є вирішальним для майбутнього, оскільки спалювання біомаси рослин супроводжується зменшенням викиду оксидів сірки та оксидів азоту. Мета роботи полягала у визначенні основних енергетичних та механічних властивостей гранул, виготовлених з єрусалимського артишоку. Механічні властивості та особливості згоряння вивчено за допомогою визначення механічної міцності (Zwick / Roell Z010) та термогравіметричного аналізу (ТГА). Придатність гранул визначається як їхньою енергетичною цінністю, на яку впливає вологість біомаси, так і механічною довговічністю під час їх транспортування та зберігання. Аналізи виконано в лабораторії кафедри біоенергетики та аналізу харчових продуктів Жешівського університету в 2017 році. Проаналізовані параметри: теплотвірна здатність, вміст вологи, вміст золи, вуглецю (C), азоту (N) та водню (Н). Досліджуваний матеріал характеризувався високими механічними рівнями опору. Встановлені експериментально висока енергетична цінність - 18,85 МДж/кг та механічна міцність, дають підставу стверджувати, що єрусалимський артишок у формі виготовлених гранул можна використовувати для опалення. Дослідженням хімічних властивостей встановлено, що цей продукт є екологічно чистим - викиди $\mathrm{CO}_{2}$ під час спалювання дорівнюють сумі $\mathrm{CO}_{2}$, що поглинає рослина під час іiї росту, що означає, що в атмосферу не викидається додаткова кількість $\mathrm{CO}_{2}$,

\footnotetext{
Запаловська Аніта - доцент, кандидат наук, кафедра біоенергетики та аналізу харчових продуктів, Жешівський університет, 35601, Жешів, вул. Желверовіча, 4, тел. 177854943, e-mail: ztbwbr@ur.edu.pl, Польща. Тел.: 0048784702111. E-mail: anise@ interia.pl

Башуцьька Уляна - доцент, кандидат сільськогосподарських наук, кафедра екології, Національний лісотехнічний університет України, 79057, Львів, вул. Ген. Чупринки, 134, тел. 0322388194, e-mail: ecology@nltu.edu.ua, Україна. Тел. 00380676837277. E-mail: ulyana_b@ukr.net
}

а також не виділяються неприємні запахи. Гранули були механічно стабільними, чистими, безпечними і зручними у використанні.

Ключові слова: біомаса, гранули, механічна міцність, енергетична цінність, єрусалимський артишок

\section{Качественный анализ гранул, полученных из иерусалимского артишока (Helianthus tuberosus L.)}

\section{А. Запаловска', У. Башуцкая²}

Развитие возобновляемой энергии является решающим для будущего, поскольку сжигание биомассы растений сопровождается уменьшением выброса оксидов серы и оксидов азота. Цель работы заключалась в определении основных энергетических и механических свойств гранул, изготовленных из иерусалимского артишока. Механические свойства и особенности сгорания изучены с помощью определения механической прочности (Zwick / Roell Z010) и термогравиметрического анализа (ТГА). Пригодность гранул определяется как их энергетической ценностью, на которую влияет влажность биомассы, так и механической долговечностью при их транспортировке и хранении. Анализы выполнены в лаборатории кафедры биоэнергетики и анализа пищевых продуктов Жешовского университета в 2017 году. Проанализированы параметры: теплотворная способность, содержание влаги, содержание золы, углерода $(\mathrm{C})$, азота $(\mathrm{N})$ и водорода $(\mathrm{H})$. Исследуемый материал характеризовался высокими механическими уровнями сопротивления. Установленные экспериментально высокие показатели энергетической ценности - 18,85 МДж/кг и механической прочности, позволяют утверждать, что иерусалимский артишок в форме изготовленных гранул можно использовать для отопления. Исследованием химических свойств установлено, что данный продукт является экологически чистым - выбросы $\mathrm{CO}_{2}$ при сжигании равны сумме $\mathrm{CO}_{2}$, которая поглощается растением во время роста, что означает, что в атмосферу не выбрасывается дополнительное количество $\mathrm{CO}_{2}$, а также не выделяются неприятные запахи. Гранулы были механически стабильными, чистыми, безопасными и удобными в использовании.

Ключевые слова: биомасса, гранулы, механическая прочность, энергетическая ценность, иерусалимский артишок

Запаловска Анита - доцент, кандидат наук, кафедра биоэнергетики и анализа пищевых продуктов, Жешовский университет, 35601, Жешов, ул. Желверовича, 4, тел. 177854943, e-mail: ztbwbr@ur.edu.pl, Польша. Тел.: 0048784702111. E-mail: anise@ interia.pl

Башуиякая Ульяна - доцент, кандидат сельскохозяйственных наук, кафедра экологии, Национальный лесотехнический университет Украины, 79057, Львов, ул. Ген. Чупрынки, 134, тел. 0322388194, e-mail: ecology@nltu.edu.ua, Украина. Тел. 00380676837277. E-mail: ulyana_b@ukr.net 